\title{
Phenolics from Mikania micrantha and Their Antioxidant Activity
}

\author{
Li-Mei Dong ${ }^{1, \dagger}{ }^{+}$Xu-Chao Jia ${ }^{2,+}{ }^{+}$, Qing-Wen Luo ${ }^{3}$, Qiang Zhang ${ }^{3}$, Bi Luo ${ }^{3}$, Wen-Bin Liu ${ }^{3}$, \\ Xu Zhang ${ }^{1}$, Qiao-Lin $\mathrm{Xu}^{4, *}$ and Jian-Wen Tan ${ }^{1,3, *}$ \\ 1 State Key Laboratory for Conservation and Utilization of Subtropical Agro-bioresources/Guangdong Key \\ Laboratory for Innovative Development and Utilization of Forest Plant Germplasm, College of Forestry and \\ Landscape Architecture, South China Agricultural University, Guangzhou 510642, China; \\ donglimei1990@163.com (L.-M.D.); zhangxu919@hotmail.com (X.Z.) \\ 2 Key Laboratory of Functional Foods, Ministry of Agriculture/Guangdong Key Laboratory of Agricultural \\ Products Processing/Sericultural \& Agri-food Research Institute, Guangdong Academy of Agricultural \\ Sciences, Guangzhou 510610, China; jiaxuchao@126.com \\ 3 Guangdong Provincial Key Laboratory of Applied Botany, South China Botanical Garden, Chinese Academy \\ of Sciences, Guangzhou 510650, China; luoyaa@foxmail.com (Q.-W.L.); zqiang55@126.com (Q.Z.); \\ bluo023@163.com (B.L.); liuwenbin15@mails.ucas.ac.cn (W.-B.L.) \\ 4 Guangdong Provincial Key Laboratory of Bio-control for the Forest Disease and Pest, Guangdong Academy \\ of Forestry, Guangzhou 510520, China \\ * Correspondence: qlxu@sinogaf.cn (Q.-L.X.); jwtan@scau.edu.cn (J.-W.T.); \\ Tel.: +86-208-702-9780 (Q.-L.X.); +86-208-528-0256 (J.-W.T.) \\ + These authors contributed equally to this work.
}

Received: 22 June 2017; Accepted: 5 July 2017; Published: 8 July 2017

\begin{abstract}
A phytochemical study on the aerial parts of Mikania micrantha led to the isolation of two new phenolic compounds, benzyl 5-O- $\beta$-D-glucopyranosyl-2,5-dihydroxybenzoate (1) and $(7 S, 8 R)$-threo-dihydroxydehydrodiconiferyl alcohol 9-acetate (2), together with twelve known compounds, benzyl 2-O- $\beta$-D-glucopyranosyl-2,6-dihydroxybenzoate (3), 4-allyl-2,6-dimethoxyphenol glucoside (4), (+)-isolariciresinol (5), icariol $\mathrm{A}_{2}$ (6), 9,10-dihydroxythymol (7), 8,9,10-trihydroxythymol (8), caffeic acid (9), $p$-coumaric acid (10), ethyl protocatechuate (11), procatechuic aldehyde (12), 4-hydroxybenzoic acid (13), and hydroquinone (14). Their structures were elucidated on the basis of extensive spectroscopic analysis. Except $\mathbf{8}$ and $\mathbf{9}$, all the other compounds were isolated from this plant species for the first time. The antioxidant activity of those isolated compounds were evaluated using three different assays. Compounds 1, 2, 3, 9, 10, 13, and 14 demonstrated significant 2,2'-azinobis-(3-ethylbenzthiazoline-6-sulphonic acid) (ABTS) free radical cation scavenging activity ranging from $\mathrm{SC}_{50} 0.31$ to $4.86 \mu \mathrm{M}$, which were more potent than L-ascorbic acid $\left(\mathrm{SC}_{50}=10.48 \mu \mathrm{M}\right)$. Compounds 5, 9, 11, and 12 exhibited more potent 1,1-diphenyl-2-picrylhydrazyl (DPPH) radical scavenging activity $\left(\mathrm{SC}_{50}=16.24-21.67 \mu \mathrm{M}\right)$ than L-ascorbic acid $(39.48 \mu \mathrm{M})$. Moreover, the ferric reducing antioxidant power (FRAP) of compounds 2, 5, 9, and 11 were discovered to be also comparable to or even more potent than L-ascorbic acid.
\end{abstract}

Keywords: Mikania micrantha; phenolic compounds; antioxidant activity

\section{Introduction}

Mikania micrantha H. B. K., belonging to the Asteraceae family, is a fast-growing perennial creeping vine indigenous to Central and South America. This plant is known as an invasive species in Southeast Asia and the Pacific region, including southern China [1]. The rapid spread of M. micrantha in South China has caused great damage to agriculture and forestry, as well as the ecological balance in invaded areas [1]. M. micrantha has long been used as a traditional herbal medicine in Jamaica to treat skin 
itches and athlete's foot [2]. Previous phytochemical studies have reported some structurally diverse chemicals from this plant, including sesquiterpene lactones, flavonoids, steroids, diterpene glucosides, and phenolic compounds, some of which have shown significant bioactivities [3-12]. Our recent study on this plant also revealed a group of rare C-9 hydroxylated ent-kaurene diterpene glucosides [13]. During our ongoing phytochemical research on invasive plants in China [14-19], two new (1 and 2) and twelve known (3-14) phenolic compounds (Figure 1), were further isolated from the aerial parts of $M$. micrantha. Herein, we report the isolation and structure elucidation of these compounds, as well as their antioxidant activity.

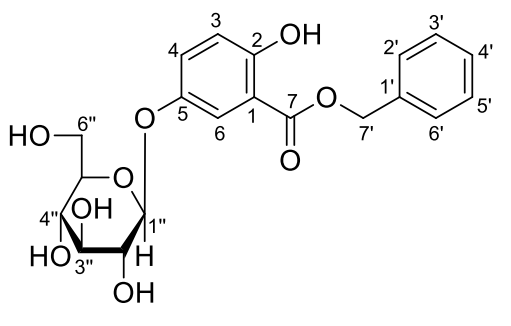

1<smiles>C=CCc1cc(OC)c(OC2OC3C(O)C(O)OC(CO)(O2)C3O)c(OC)c1</smiles>

4<smiles>Cc1ccc(C(CO)CO)c(O)c1</smiles>

7<smiles>CCOC(=O)c1ccc(O)c(O)c1</smiles>

11<smiles>COc1cc([C@@H]2Oc3c(OC)cc(C(O)C(O)CO)cc3[C@@H]2COC(C)=O)ccc1O</smiles>

2<smiles>COc1cc([C@H]2c3cc(O)c(OC)cc3[C@H](CO)C[C@H]2CO)ccc1O</smiles>

5<smiles>Cc1ccc(C(O)(CO)CO)c(O)c1</smiles>

8<smiles>O=Cc1ccc(O)c(O)c1</smiles>

12<smiles>O=C(O)/C=C/c1ccc(O)c(O)c1</smiles>

9<smiles>O=C(O)c1ccc(O)cc1</smiles>

13<smiles>O=C(OCc1ccccc1)c1c(O)cccc1OC1C(O)C2OC3(CO)OC(O)C(OC13)C2O</smiles>

3<smiles>COc1cc([C@H]2O[C@@H](c3cc(OC)c(O)c(OC)c3)[C@H](CO)[C@H]2CO)cc(OC)c1O</smiles>

6<smiles>O=C(O)/C=C/c1ccc(O)cc1</smiles>

10<smiles>Oc1ccc(O)cc1</smiles>

14

Figure 1. Chemical structures of compounds 1-14.

\section{Results and Discussion}

Compound 1 was obtained as a colorless syrup and deduced to have the molecular formula $\mathrm{C}_{20} \mathrm{H}_{22} \mathrm{O}_{9}$ from its HR-ESI-MS data, $m / z 441.0971\left[\mathrm{M}+\mathrm{Cl}^{-}\right.$(calcd for $\mathrm{C}_{20} \mathrm{H}_{22} \mathrm{O}_{9} \mathrm{Cl}^{-}$, 441.0958), which required ten degrees of unsaturation. The ${ }^{1} \mathrm{H}$ and ${ }^{13} \mathrm{C}-\mathrm{NMR}$ spectra of $\mathbf{1}$ (Table 1), coupled with HSQC analysis, indicated twenty carbons, including two methylenes, thirteen methines, and five quaternary carbons including one carboxyl group at $\delta_{\mathrm{C}} 168.1(\mathrm{C}-7)$. The signals of $\delta_{\mathrm{H}} 4.69(1 \mathrm{H}, \mathrm{d}, J=7.6 \mathrm{~Hz}$, $\left.\mathrm{H}-1^{\prime \prime}\right)$ and $\delta_{C} 60.6\left(\mathrm{C}-6^{\prime \prime}\right), 69.6\left(\mathrm{C}-4^{\prime \prime}\right), 73.2\left(\mathrm{C}-2^{\prime \prime}\right), 77.0\left(\mathrm{C}-3^{\prime \prime}\right), 76.5\left(\mathrm{C}-5^{\prime \prime}\right)$, and $101.9\left(\mathrm{C}-1^{\prime \prime}\right)$ indicated the presence of a $\beta$-D-glucopyranosyl moiety in the molecule. The presence of a benzyl moiety in the molecule was suggested by the proton signals at $\delta_{\mathrm{H}} 7.49\left(2 \mathrm{H}, \mathrm{m}, \mathrm{H}-2^{\prime}, 6^{\prime}\right), 7.42\left(2 \mathrm{H}, \mathrm{m}, \mathrm{H}-3^{\prime}, 5^{\prime}\right)$, 
$7.37\left(1 \mathrm{H}, \mathrm{m}, \mathrm{H}-4^{\prime}\right)$, and $5.37\left(2 \mathrm{H}, \mathrm{m}, \mathrm{H}-7^{\prime}\right)$, and further supported by the carbon signals at $\delta_{\mathrm{C}} 128.1$ $\left(\mathrm{C}-2^{\prime}, 6^{\prime}\right), 128.6\left(\mathrm{C}-3^{\prime}, 5^{\prime}\right), 128.3\left(\mathrm{C}-4^{\prime}\right)$, and $66.6\left(\mathrm{C}-7^{\prime}\right)$. Besides, the presence of an ABX spin system was ascertained by the characteristic proton signals of two doublets at $\delta_{\mathrm{H}} 6.94(1 \mathrm{H}, \mathrm{d}, J=9.0 \mathrm{~Hz}, \mathrm{H}-3)$ and $7.44(1 \mathrm{H}, \mathrm{d}, J=3.1 \mathrm{~Hz}, \mathrm{H}-6)$, a double doublet at $\delta_{\mathrm{H}} 7.28(1 \mathrm{H}, \mathrm{dd}, J=9.0,3.1 \mathrm{~Hz}, \mathrm{H}-4)$, and further confirmed by the ${ }^{13} \mathrm{C}-\mathrm{NMR}$ and HSQC spectra, which revealed three aromatic quaternary carbons at $\delta_{C} 112.9(\mathrm{C}-1), 155.3(\mathrm{C}-2)$, and 149.9 (C-5), and three aromatic methine carbons at $\delta_{C} 118.3(\mathrm{C}-3)$, 125.2 (C-4), and 117.0 (C-6). After a more carefully study of the aforementioned NMR data and taking into account the proposed molecular formula, it could be deduced that a free hydroxyl $(\mathrm{OH})$ group would exist in the molecule. In the HMBC spectrum (Figure 2), correlation signals from $\delta_{\mathrm{H}} 10.14$ $(\mathrm{OH}-2)$ to $\delta_{\mathrm{C}} 112.9(\mathrm{C}-1), 118.3(\mathrm{C}-3)$, and $155.3(\mathrm{C}-2)$ was observed, which revealed the position of the hydroxyl group at $\mathrm{C}-2$. The observation of significant $\mathrm{HMBC}$ correlation from $\delta_{\mathrm{H}} 4.69\left(\mathrm{H}-1^{\prime \prime}\right)$ to $\delta_{\mathrm{C}}$ 149.9 (C-5) verified the location of the glucopyranosyl moiety at C-5. The HMBC correlations from $\delta_{\mathrm{H}} 6.94(\mathrm{H}-3)$ and $7.44(\mathrm{H}-6)$ to $\delta_{\mathrm{C}} 168.1(\mathrm{C}-7)$ proved the connection of the carboxyl group to $\mathrm{C}-1$. In addition, the ester bond linkage of $\mathrm{C}-7$ with $\mathrm{C}-7^{\prime}$ was supported by the observation of significant $\mathrm{HMBC}$ correlation from $\delta_{\mathrm{H}} 5.37\left(\mathrm{H}-7^{\prime}\right)$ to $\delta_{\mathrm{C}} 168.1$ (C-7). Therefore, compound 1 was established as benzyl 5-O- $\beta$-D-glucopyranosyl-2,5-dihydroxybenzoate.

Table 1. The ${ }^{1} \mathrm{H}(500 \mathrm{MHz})$ and ${ }^{13} \mathrm{C}(125 \mathrm{MHz})$ nuclear magnetic resonance (NMR) data of compounds 1 and 2.

\begin{tabular}{|c|c|c|c|c|c|}
\hline \multirow{2}{*}{$\mathrm{H} / \mathrm{C}$} & \multicolumn{2}{|l|}{$1^{a}$} & \multirow{2}{*}{$\mathrm{H} / \mathrm{C}$} & \multicolumn{2}{|l|}{$2^{b}$} \\
\hline & $\delta_{H}($ mult,$J$ in $\mathrm{Hz})$ & $\delta_{C}$ & & $\delta_{\mathrm{H}}($ mult, $J$ in $\mathrm{Hz})$ & $\delta_{C}$ \\
\hline 1 & & $112.9(\mathrm{C})$ & 1 & & $133.8(\mathrm{C})$ \\
\hline 2 & & $155.3(\mathrm{C})$ & 2 & $6.96(\mathrm{~d}, 1.9)$ & $110.6(\mathrm{CH})$ \\
\hline 3 & $6.94(\mathrm{~d}, 9.0)$ & $118.3(\mathrm{CH})$ & 3 & & $149.2(\mathrm{C})$ \\
\hline 4 & $7.28(\mathrm{dd}, 9.0,3.1)$ & $125.2(\mathrm{CH})$ & 4 & & $147.8(\mathrm{C})$ \\
\hline 5 & & $149.9(\mathrm{C})$ & 5 & $6.79(\mathrm{~d}, 8.1)$ & $116.2(\mathrm{CH})$ \\
\hline 6 & $7.44(\mathrm{~d}, 3.1)$ & $117.0(\mathrm{CH})$ & 6 & $6.84(\mathrm{dd}, 8.1,1.9)$ & $120.0(\mathrm{CH})$ \\
\hline 7 & & $168.1(\mathrm{C})$ & 7 & $5.48(\mathrm{~d}, 7.0)$ & $89.7(\mathrm{CH})$ \\
\hline $1^{\prime}$ & & $135.6(\mathrm{C})$ & 8 & $3.76(\mathrm{dd}, 13.0,7.0)$ & $51.9(\mathrm{CH})$ \\
\hline $2^{\prime}$ & $7.49(\mathrm{~m})$ & $128.1(\mathrm{CH})$ & 9 & $\begin{array}{l}4.33(\mathrm{dd}, 11.1,7.6) \\
4.44(\mathrm{dd}, 11.1,5.4)\end{array}$ & $66.7\left(\mathrm{CH}_{2}\right)$ \\
\hline $3^{\prime}$ & $7.42(\mathrm{~m})$ & $128.6(\mathrm{CH})$ & $1^{\prime}$ & & $137.3(\mathrm{C})$ \\
\hline $4^{\prime}$ & $7.37(\mathrm{~m})$ & $128.3(\mathrm{CH})$ & $2^{\prime}$ & $6.98(\mathrm{~s})$ & $112.9(\mathrm{CH})$ \\
\hline $5^{\prime}$ & $7.42(\mathrm{~m})$ & $128.6(\mathrm{CH})$ & $3^{\prime}$ & & $145.4(\mathrm{C})$ \\
\hline $6^{\prime}$ & $7.49(\mathrm{~m})$ & $128.1(\mathrm{CH})$ & $4^{\prime}$ & & $148.8(\mathrm{C})$ \\
\hline $7^{\prime}$ & $5.37(\mathrm{~m})$ & $66.6\left(\mathrm{CH}_{2}\right)$ & $5^{\prime}$ & & $128.7(\mathrm{C})$ \\
\hline $1^{\prime \prime}$ & $4.69(\mathrm{~d}, 7.6)$ & $101.9(\mathrm{CH})$ & $6^{\prime}$ & $6.93(\mathrm{~s})$ & $116.5(\mathrm{CH})$ \\
\hline $2^{\prime \prime}$ & $3.20(\mathrm{~m})$ & $73.2(\mathrm{CH})$ & $7^{\prime}$ & $4.59(\mathrm{~d}, 6.0)$ & $75.3(\mathrm{CH})$ \\
\hline $3^{\prime \prime}$ & $3.24(\mathrm{~m})$ & $77.0(\mathrm{CH})$ & $8^{\prime}$ & $3.68(\mathrm{dd}, 4.2,6.0)$ & $77.6(\mathrm{CH})$ \\
\hline $4^{\prime \prime}$ & $3.16(\mathrm{~m})$ & $69.6(\mathrm{CH})$ & $9^{\prime}$ & $\begin{array}{l}3.40(\mathrm{dd}, 11.1,6.3) \\
4.44(\mathrm{dd}, 11.1,4.2)\end{array}$ & $64.3\left(\mathrm{CH}_{2}\right)$ \\
\hline $5^{\prime \prime}$ & $3.24(\mathrm{~m})$ & $76.5(\mathrm{CH})$ & OMe-3 & $3.83(\mathrm{~s})$ & $56.4\left(\mathrm{CH}_{3}\right)$ \\
\hline $6^{\prime \prime}$ & $\begin{array}{l}3.48(\mathrm{dd}, 11.8,3.5) \\
3.63(\mathrm{dd}, 11.8,6.0)\end{array}$ & $60.6\left(\mathrm{CH}_{2}\right)$ & OMe-3' & $3.89(\mathrm{~s})$ & $56.7\left(\mathrm{CH}_{3}\right)$ \\
\hline $\mathrm{OH}-2$ & $10.14(\mathrm{~s})$ & & OAc & & $172.7(\mathrm{C})$ \\
\hline & & & & $2.02(\mathrm{~s})$ & $20.7\left(\mathrm{CH}_{3}\right)$ \\
\hline
\end{tabular}

${ }^{\mathrm{a}}$ Recorded in DMSO- $d_{6} ;{ }^{\mathrm{b}}$ Recorded in $\mathrm{CD}_{3} \mathrm{OD}$. 

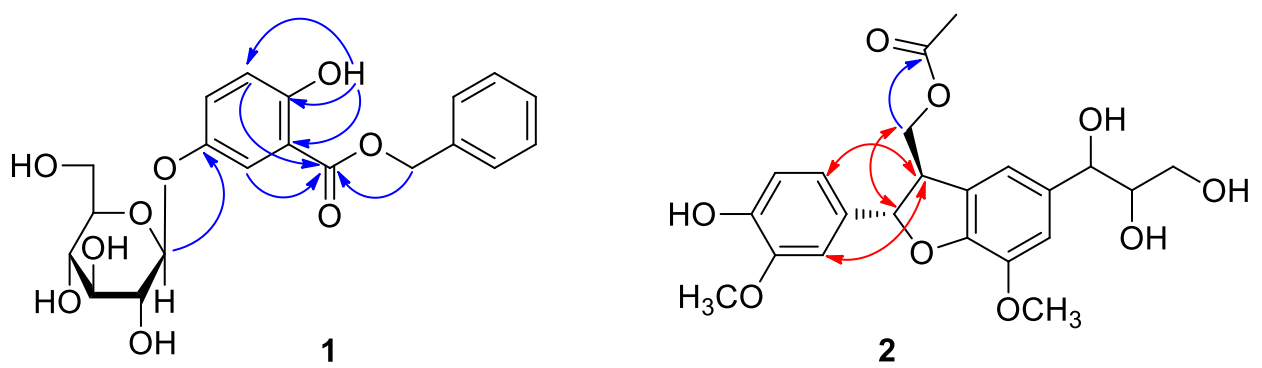

Figure 2. Key HMBC (blue arrows) and NOE (red arrows) correlations of $\mathbf{1}$ and $\mathbf{2}$.

Compound 2, obtained as a colorless oil, was determined to have the molecular formula $\mathrm{C}_{22} \mathrm{H}_{26} \mathrm{O}_{9}$ according to its HR-ESI-MS data, $m / z 457.1467[\mathrm{M}+\mathrm{Na}]^{+}$(calcd for $\mathrm{C}_{22} \mathrm{H}_{26} \mathrm{O}_{9} \mathrm{Na}^{+}$, 457.1469), which required ten degrees of unsaturation. The ${ }^{1} \mathrm{H}-\mathrm{NMR}$ spectrum (Table 1) showed signals of an acetoxy methyl at $\delta_{\mathrm{H}} 2.02(3 \mathrm{H}, \mathrm{s})$, two methoxy groups at $\delta_{\mathrm{H}} 3.83(3 \mathrm{H}, \mathrm{s})$ and $3.89(3 \mathrm{H}, \mathrm{s})$, and five aromatic protons. The ${ }^{13} \mathrm{C}-\mathrm{NMR}$ spectrum (Table 1), coupled with HSQC analysis, exhibited the signals of twenty-two carbons in total, comprising three methyls, two oxymethylenes $\left[\delta_{C} 64.3\left(C-9^{\prime}\right)\right.$ and 66.7 (C-9)], nine methines (including five aromatic methanes), and eight quaternary carbons [including a carboxyl group at $\delta_{C} 172.7$ and seven aromatic quaternary carbons]. Detailed analysis of the NMR data indicated that compound 2 closely resembled threo-dihydroxydehydrodiconiferyl alcohol [20-22], with the only difference of the hydroxyl group at C-9 being replaced by an acetoxy group in 2 . This deduction was consistent with the molecular formula and in accord with the significant HMBC correlations (Figure 2) from $\delta_{\mathrm{H}} 4.33$ and 4.44 (C-9) to $\delta_{\mathrm{C}} 172.7$. The relative configuration of $\mathrm{H}-7$ and $\mathrm{H}-8$ was determined to be trans, as supported by the NOE correlations of $\mathrm{H}-7 / \mathrm{H}-9$ and $\mathrm{H}-8 / \mathrm{H}-6$, H-2 (Figure 2). The absolute configuration of C-7 and C-8 in 2 was assigned to be $S$ and $R$ based on the positive CD Cotton effects at $292 \mathrm{~nm}$ and $240 \mathrm{~nm}$ and the negative Cotton effect at $224 \mathrm{~nm}$ [23,24]. Furthermore, according to literature reports about that the chemical shifts of the C-7' and C-8 ${ }^{\prime}$ and the value of $\Delta \delta_{C 8^{\prime}-C 7^{\prime}}$ are characteristically different for the threo and erythro isomers, the relative configuration of $\mathrm{C}-7^{\prime}$ and $\mathrm{C}-8^{\prime}$ in 2 could then be determined to be threo based on its ${ }^{13} \mathrm{C}$-NMR data at $\delta_{\mathrm{C}} 75.3\left(\mathrm{C}-7^{\prime}\right)$ and $77.6\left(\mathrm{C}-8^{\prime}\right)$ with the value of $\Delta \delta_{\mathrm{C} 8^{\prime}-\mathrm{C} 7^{\prime}}>2.0 \mathrm{ppm}$ [25-27]. Hence, compound 2 was elucidated as $(7 S, 8 R)$-threo-dihydroxydehydrodiconiferyl alcohol 9-acetate.

The twelve known compounds were identified as benzyl 2-O- $\beta$-D-glucopyranosyl-2,6dihydroxybenzoate (3) [28], 4-allyl-2,6-dimethoxyphenol glucoside (4) [29], (+)-isolariciresinol (5) [30], icariol $\mathrm{A}_{2}$ (6) [31], 9,10-dihydroxythymol (7) [32], 8,9,10-trihydroxythymol (8) [11], caffeic acid (9) [33], p-coumaric acid (10) [34], ethyl protocatechuate (11) [35], procatechuic aldehyde (12) [33], 4-hydroxybenzoic acid (13) [36], and hydroquinone (14) [37] by comparison of their NMR and ESI-MS data with those reported in the literature. All the known compounds, except $\mathbf{8}$ and $\mathbf{9}$, were isolated from this plant species for the first time.

All of the isolated compounds were measured for their antioxidant activity by using three different in vitro assays, i.e., ABTS radical cation $\left(\mathrm{ABTS}^{\bullet+}\right)$ scavenging assay, DPPH radical $\left(\mathrm{DPPH}^{\bullet}\right)$ scavenging assay, and FRAP assay, with L-ascorbic acid as a reference compound. As shown in Table 2, new compounds 1 and 2, and known compounds 3, 9, 10, 13, and 14 demonstrated ABTS radical cation scavenging activity with $\mathrm{SC}_{50}$ values ranging from 0.31 to $4.86 \mu \mathrm{M}$, which were more potent than L-ascorbic acid $\left(\mathrm{SC}_{50}=10.48 \mu \mathrm{M}\right)$. Compounds 5, 9, 11, and 12 exhibited more potent $\mathrm{DPPH}$ radical scavenging activity $\left(\mathrm{SC}_{50}=16.24-21.67 \mu \mathrm{M}\right)$ than L-ascorbic acid $\left(\mathrm{SC}_{50}=39.48 \mu \mathrm{M}\right)$. Moreover, the revealed ferric reducing antioxidant power (FRAP) of compounds 2, 5, 9, and 11 were also comparable to or even more potent than the reference compound. 
Table 2. Antioxidant activity of compounds 1-14.

\begin{tabular}{cccc}
\hline Compound & ABTS $\left(\mathbf{S C}_{\mathbf{5 0}}, \boldsymbol{\mu M}\right)$ & DPPH $_{\left(\mathbf{S C}_{\mathbf{5 0}}, \boldsymbol{\mu M}\right)}$ & FRAP $(\mathbf{m m o l} / \mathbf{g})$ \\
\hline $\mathbf{1}$ & $0.31 \pm 0.02$ & $>100$ & $0.54 \pm 0.03$ \\
$\mathbf{2}$ & $4.19 \pm 0.05$ & $>100$ & $12.28 \pm 0.25$ \\
$\mathbf{3}$ & $1.83 \pm 0.07$ & $>100$ & $1.01 \pm 0.17$ \\
$\mathbf{4}$ & $>50$ & $>100$ & $1.41 \pm 0.15$ \\
$\mathbf{5}$ & $9.40 \pm 0.13$ & $21.67 \pm 2.27$ & $13.12 \pm 0.23$ \\
$\mathbf{6}$ & $31.81 \pm 0.17$ & $34.24 \pm 0.39$ & $5.08 \pm 0.08$ \\
$\mathbf{7}$ & $>50$ & $>100$ & $0.05 \pm 0.00$ \\
$\mathbf{8}$ & $6.54 \pm 0.07$ & $>100$ & $1.13 \pm 0.25$ \\
$\mathbf{9}$ & $4.69 \pm 0.19$ & $16.24 \pm 0.31$ & $20.86 \pm 0.24$ \\
$\mathbf{1 0}$ & $3.48 \pm 0.16$ & $>100$ & $3.12 \pm 0.05$ \\
$\mathbf{1 1}$ & $18.23 \pm 0.36$ & $20.57 \pm 0.29$ & $10.87 \pm 0.18$ \\
$\mathbf{1 2}$ & $9.30 \pm 0.01$ & $16.59 \pm 0.24$ & $7.79 \pm 0.12$ \\
$\mathbf{1 3}$ & $4.86 \pm 0.22$ & $>100$ & $2.57 \pm 0.07$ \\
$\mathbf{1 4}$ & $4.57 \pm 0.27$ & $31.96 \pm 1.24$ & $8.77 \pm 0.22$ \\
L-ascorbic acid & $10.48 \pm 0.07$ & $39.48 \pm 0.38$ & $11.32 \pm 0.13$ \\
\hline \multicolumn{5}{r}{ Each value represents mean \pm standard deviation $(\mathrm{n}=3)}$.
\end{tabular}

Generally, free radicals and reactive oxygen species (ROS) are formed unceasingly in human body and the normal presence of free radicals can produce beneficial oxidation during physiological events. However, excessive generation of free radicals in human body will bring harmful oxidation to organisms, which is recognized as a leading cause of a variety of chronic diseases such as atherosclerosis, angiocardiopathy and cancer [38,39]. It is well known that natural antioxidants can help prevent oxidation and help regulate immune function. This study, to some extent, indicate that the invasive plant $M$. micrantha is rich in structurally diverse natural antioxidants, at least in antioxidant phenolic compounds, which are potential functional chemicals beneficial for human health worthy of further investigation.

\section{Materials and Methods}

\subsection{General Experimental Procedures}

Nuclear magnetic resonance (NMR) spectra were recorded on a Bruker DRX-500 NMR spectrometer (Bruker Biospin Gmbh, Rheistetten, Germany). Electrospray ionization mass spectrometry (ESI-MS) was measured on a MDS SCIEX API 2000 LC/MS/MS apparatus (Applied Biosystems Inc., Forster, CA, USA). High-resolution (HR) ESI-MS was measured on a Bruker Bio TOF IIIQ spectrometer (Bruker Daltonics, Billerica, MA, USA). Optical rotations were obtained on a Perkin-Elmer Model 341 polarimeter (Perkin-Elmer, Inc., Waltham, MA). UV spectra were acquired on a Perkin-Elmer Lambda 650 UV-Vis spectrometer (Perkin-Elmer, Inc., Waltham, MA, USA). Preparative HPLC was performed with an HPLC system epuipped with a Shimadzu LC-6AD pump and a Shimadzu RID-10A refractive index detector using a Shim-pack PRC-ODS C-18 column $(5 \mu \mathrm{m}, 20 \mathrm{~mm} \times 250 \mathrm{~mm})$. Medium pressure liquid chromatography (MPLC) was carried out on a CXTH P3000 instrument (Beijing Chuang Xin Tong Heng Science and Technology Co., Ltd, Beijing, China) equipped with a UV 3000 UV-Vis Detector and a C-18 column $(50 \mu \mathrm{m}, 50 \mathrm{~mm} \times 500 \mathrm{~mm})$.

Silica gel (80-100 and 200-300 mesh, Qingdao Haiyang Chemical Co., Qingdao, China), and Sephadex LH-20 (Pharmacia Fine Chemical Co., Ltd., Oppsala, Sweden) were used for open column chromatography (CC). Thin-layer chromatography (TLC) was conducted on precoated silica gel plates (HSGF 254 , Yantai Jiangyou Silica Gel Development Co., Ltd., Yantai, China) and spot detection was performed by spraying $10 \% \mathrm{H}_{2} \mathrm{SO}_{4}$ in ethanol, followed by heating. DPPH, ABTS and 2,4,6-Tripyridy-s-triazine (TPTZ) were purchased from Sigma-Aldrich (Shanghai) Trading Co. (Shanghai, China). Phosphate buffered saline (PBS) and L-ascorbic acid were obtained from Life 
technologies (Thermo Fisher Scientific, Shanghai, China) and Shanghai Boao Biotech Co. (Shanghai, China), respectively.

\subsection{Plant Material}

The aerial parts of M. micrantha were collected from Guangzhou, China, in July 2014, and identified by Prof. Hong-Feng Chen, South China Botanical Garden, Chinese Academy of Sciences (CAS). A voucher specimen (No. 20140705) was deposited at the Laboratory of Bioorganic Chemistry of the South China Botanical Garden, CAS.

\subsection{Extraction and Isolation}

Powdered air-dried aerial parts of M. micrantha $(18.5 \mathrm{~kg}$ ) were extracted three times (each time for three days) with $95 \% \mathrm{EtOH}(50 \mathrm{~L})$ at room temperature. The $\mathrm{EtOH}$ extract, after concentration in vacuo, was suspended in water $(3 \mathrm{~L})$ and then sequentially extracted three times each with petroleum ether $(3 \mathrm{~L})$ and EtOAc $(3 \mathrm{~L})$ to yield a petroleum ether-soluble fraction $(520 \mathrm{~g})$, and an EtOAc-soluble fraction ( $260 \mathrm{~g}$ ) after condensation to dryness under vacuum. The EtOAc-soluble fraction was subjected to silica gel column chromatography, eluted with an increasing polarity of $\mathrm{CHCl}_{3} / \mathrm{MeOH}$ (from 98:2 to $70: 30, v / v$, each $18 \mathrm{~L}$ ) to afford fractions $\mathrm{E}_{1}-\mathrm{E}_{6}$ after pooling according to their TLC profiles. Fraction $\mathrm{E}_{3}$ (20 g), obtained on elution with $\mathrm{CHCl}_{3} / \mathrm{MeOH}$ (95:5), was separated by MPLC using a decreasing polarity of $\mathrm{MeOH} / \mathrm{H}_{2} \mathrm{O}(35: 65-100: 0, v / v$, each $1 \mathrm{~L})$ system at the flow rate of $8 \mathrm{~mL} / \mathrm{min}$ to give fractions $\mathrm{E}_{3-1}-\mathrm{E}_{3-20}$. Fraction $\mathrm{E}_{3-2}$, obtained from the elution with $\mathrm{MeOH} / \mathrm{H}_{2} \mathrm{O}$ (35:65), was applied on Sephadex LH-20 column chromatography with the elution of $\mathrm{CHCl}_{3} / \mathrm{MeOH}(1: 4, v / v)$, to provide fractions $E_{3-2-1}-E_{3-2-4}$. $E_{3-2-4}$ was purified by preparative HPLC with a Shim-pack PRC-ODS C-18 column $(5 \mu \mathrm{m}, 20 \mathrm{~mm} \times 250 \mathrm{~mm})$ using $10 \%$ acetonitrile in water $(v / v)$ as a mobile phase at the flow rate of $8 \mathrm{~mL} / \mathrm{min}$ to obtain $12\left(9 \mathrm{mg}, \mathrm{t}_{\mathrm{R}}=78 \mathrm{~min}\right)$ and $\mathbf{6}\left(3 \mathrm{mg}, \mathrm{t}_{\mathrm{R}}=110 \mathrm{~min}\right)$. Fraction $\mathrm{E}_{3-8}$ was applied on $\mathrm{LH}-20 \mathrm{CC}$ with the elution of $\mathrm{CHCl}_{3} / \mathrm{MeOH}(1: 4, v / v)$ to furnish $5(5 \mathrm{mg})$, and $\mathbf{1 0}(9 \mathrm{mg})$. Fraction $\mathrm{E}_{4}(18.8 \mathrm{~g})$, obtained on elution with $\mathrm{CHCl}_{3} / \mathrm{MeOH}$ (95:5), was separated by MPLC using a decreasing polarity of $\mathrm{MeOH} / \mathrm{H}_{2} \mathrm{O}(35: 65-100: 0, v / v$, each $1 \mathrm{~L})$ system at the flow rate of $8 \mathrm{~mL} / \mathrm{min}$ to give fractions $\mathrm{E}_{4-1}-\mathrm{E}_{4-18}$. Fraction $\mathrm{E}_{4-11}$, obtained from the elution with $\mathrm{MeOH} / \mathrm{H}_{2} \mathrm{O}(45: 55)$, was applied on Sephadex LH-20 column chromatography with the elution of $\mathrm{CHCl}_{3} / \mathrm{MeOH}(1: 4, v / v)$, to provide fractions $E_{4-11-1}-E_{4-11-6}$. The fraction $E_{4-11-3}$ was further purified by preparative HPLC with a Shim-pack PRC-ODS C-18 column $(5 \mu \mathrm{m}, 20 \mathrm{~mm} \times 250 \mathrm{~mm})$ using $16 \%$ acetonitrile in water $(v / v)$ as a mobile phase at the flow rate of $8 \mathrm{~mL} / \mathrm{min}$ to obtain $2\left(2 \mathrm{mg}\right.$, $\left.\mathrm{t}_{\mathrm{R}}=78 \mathrm{~min}\right)$. Fraction $\mathrm{E}_{4-6}$ was applied on LH-20 $\mathrm{CC}$ with the elution of $\mathrm{CHCl}_{3} / \mathrm{MeOH}(1: 4, v / v)$ to furnish $7(4 \mathrm{mg}), 8(18 \mathrm{mg})$, and $\mathbf{1 3}(27 \mathrm{mg})$. Fraction $\mathrm{E}_{4-13}$ was applied on $\mathrm{LH}-20 \mathrm{CC}$ with the elution of $\mathrm{CHCl}_{3} / \mathrm{MeOH}(1: 4, v / v)$ and then purified by HPLC using $16 \%$ acetonitrile in water $(v / v)$ as mobile phase at $8 \mathrm{~mL} / \mathrm{min}$ to furnish $4\left(10 \mathrm{mg}, \mathrm{t}_{\mathrm{R}}=90 \mathrm{~min}\right)$ and $3\left(13 \mathrm{mg}, \mathrm{t}_{\mathrm{R}}=100 \mathrm{~min}\right)$. Fraction $\mathrm{E}_{5}(18.6 \mathrm{~g})$, obtained on elution with $\mathrm{CHCl}_{3} / \mathrm{MeOH}$ (90:10), was separated by MPLC using a decreasing polarity of $\mathrm{MeOH} / \mathrm{H}_{2} \mathrm{O}(10: 90-100: 0$, $v / v$, each $1 \mathrm{~L})$ system at the flow rate of $8 \mathrm{~mL} / \mathrm{min}$ to give fractions $\mathrm{E}_{5-1}-\mathrm{E}_{5-30}$. Fraction $\mathrm{E}_{5-19}$, obtained from the elution with $\mathrm{MeOH} / \mathrm{H}_{2} \mathrm{O}$ (65:35), was applied on Sephadex LH-20 column chromatography with the elution of $\mathrm{CHCl}_{3} / \mathrm{MeOH}(1: 4, v / v)$, to provide fractions $\mathrm{E}_{5-19-1}-\mathrm{E}_{5-19-6}$. The fraction $\mathrm{E}_{5-19-6}$ was further purified by preparative HPLC with a Shim-pack PRC-ODS C-18 column $(5 \mu \mathrm{m}, 20 \mathrm{~mm} \times 250 \mathrm{~mm})$ using $25 \%$ acetonitrile in water $(v / v)$ as a mobile phase at the flow rate of $8 \mathrm{~mL} / \mathrm{min}$ to obtain $\mathbf{1}(10 \mathrm{mg}$, $t_{\mathrm{R}}=65 \mathrm{~min}$ ). Fraction $\mathrm{E}_{5-2}$, was applied on $\mathrm{LH}-20 \mathrm{CC}$ with the elution of $\mathrm{CHCl}_{3} / \mathrm{MeOH}(1: 4, v / v)$ to furnish 9 (10 mg), $\mathbf{1 1}$ (5 mg), and $\mathbf{1 4}(3 \mathrm{mg})$.

Benzyl 5-O- $\beta$-D-glucopyranosyl-2,5-dihydroxybenzoate (1): Colorless syrup; $[\alpha]_{D}^{20}-22.50\left(c 0.68, \mathrm{C}_{5} \mathrm{H}_{5} \mathrm{~N}\right)$; $\mathrm{UV}\left(\mathrm{C}_{5} \mathrm{H}_{5} \mathrm{~N}\right) \lambda_{\max } \mathrm{nm}(\log \varepsilon) 251$ (4.16), 257 (4.19); HR-ESI-MS $m / z 441.0971\left[\mathrm{M}+\mathrm{Cl}^{-}\right.$(calcd for $\left.\mathrm{C}_{20} \mathrm{H}_{22} \mathrm{ClO}_{9}{ }^{-}, 441.0958\right) ;{ }^{1} \mathrm{H}-\mathrm{NMR}(500 \mathrm{MHz})$ and ${ }^{13} \mathrm{C}-\mathrm{NMR}(125 \mathrm{MHz})$ data in DMSO- $d_{6}$, see Table 1. 
(7S,8R)-threo-Dihydroxydehydrodiconiferyl alcohol 9-acetate (2): Colorless oil; $[\alpha]_{D}^{20}+45.71(c 0.07, \mathrm{MeOH})$; UV (MeOH) $\lambda_{\max } \mathrm{nm}(\log \varepsilon) 282$ (3.70); HR-ESI-MS $m / z 457.1467$ [M + Na] $]^{+}$(calcd for $\mathrm{C}_{22} \mathrm{H}_{26} \mathrm{NaO}_{9}{ }^{+}$, 457.1469); ${ }^{1} \mathrm{H}-\mathrm{NMR}(500 \mathrm{MHz})$ and ${ }^{13} \mathrm{C}-\mathrm{NMR}(125 \mathrm{MHz})$ data in $\mathrm{CD}_{3} \mathrm{OD}$, see Table 1.

\subsection{Antioxidant Activity Evaluation}

\subsubsection{ABTS Radical Cation Scavenging Assay}

The ABTS radical cation $\left(\mathrm{ABTS}^{\bullet+}\right.$ ) scavenging activity of the isolated compounds was evaluated following the procedures as previously described [40]. Briefly, potassium persulfate was added to $7 \mathrm{mM}$ of $\mathrm{ABTS}^{\bullet+}$, and the mixture was allowed to stand in the dark at room temperature for 12-16 $\mathrm{h}$ before use. The $\mathrm{ABTS}^{\bullet+}$ solution was diluted with phosphate-buffered saline (PBS, $\mathrm{pH}$ 7.4) to provide an absorbance of $0.70 \pm 0.02$ at $734 \mathrm{~nm}$. The diluted $\mathrm{ABTS}^{\bullet+}$ solution $(190 \mu \mathrm{L})$ was added to sample fractions $(10 \mu \mathrm{L})$ in DMSO at different concentrations. Each treatment was conducted in triplicate. After a mixing time of $10 \mathrm{~s}$ and an incubation period of $6 \mathrm{~min}$ at $37^{\circ} \mathrm{C}$ in the dark, the absorbance in each well was read at $415 \mathrm{~nm}$ on a Genios microplate reader (Tecan). L-Ascorbic acid was used as a positive control. The inhibitory rates of $\mathrm{ABTS}^{\bullet+}$ were calculated according to the following formula: ABTS scavenging rate $(\%)=[1-$ (absorbance of compound - absorbance of blank)/absorbance of control] $\times 100 . S_{50}$ values were calculated and expressed as means $\pm \mathrm{SD}$ in micromolar.

\subsubsection{DPPH Radical Scavenging Assay}

Scavenging activity of the compounds towards DPPH radicals was carried out by the method as previously described [40]. DPPH radical solution was freshly prepared with $\mathrm{MeOH}$ to $0.1 \mathrm{mM}$. Test compounds were dissolved in DMSO and diluted two-fold to six serial concentrations. The DPPH solution $(180 \mu \mathrm{L})$ and sample solution $(20 \mu \mathrm{L})$ were mixed in 96-well plates. L-Ascorbic acid was dissolved in methanol and used as a positive reference. The control group contained DMSO instead of the compound solution, and the blank group contained methanol in place of the DPPH solution. Each treatment was performed in quadruplicate. The plates were incubated at $37^{\circ} \mathrm{C}$ for $30 \mathrm{~min}$ in the dark. The absorbance in each well was read at $515 \mathrm{~nm}$ on a Genios microplate reader (Tecan). The inhibitory rates of DPPH radicals were calculated according to the formula: DPPH scavenging rate $(\%)=[1-($ absorbance of compound - absorbance of blank $) /$ absorbance of control $] \times 100$. $\mathrm{SC}_{50}$ values (the concentrations required to scavenge 50\% DPPH radicals present in the test solution) were calculated and expressed as means \pm SD in micromolar.

\subsubsection{FRAP Assay}

Ferric reducing ability of the compounds was conducted according to the procedures as previously described [40]. FRAP reagent was made freshly by mixing $300 \mathrm{mM}$ acetate buffer ( $\mathrm{pH}$ 3.6), $10 \mathrm{mM}$ TPTZ solution in $40 \mathrm{mM}$ hydrochloric acid, and $20 \mathrm{mM}$ aqueous ferric chloride $\left(\mathrm{FeCl}_{3}\right)$ solution in a 10:1:1 $(v / v)$ ratio. The TPTZ solution was prepared on the same day. Test compounds were dissolved in methanol and diluted 2-fold to six concentrations. Twenty microliters of the compound solution and $180 \mu \mathrm{L}$ of FRAP reagent were mixed in 96-well plates. L-Ascorbic acid was dissolved in methanol and used as a positive reference. Each treatment was conducted in quadruplicate. The plates were incubated at $37^{\circ} \mathrm{C}$ for $30 \mathrm{~min}$ in the dark. The absorbance of the product (ferrous TPTZ complex) in each well was read at $595 \mathrm{~nm}$ using a Genios microplate reader (Tecan Group, Mannedorf, Switzerland). One milliliter of ferrous sulfate $\left(\mathrm{FeSO}_{4}\right)$ at six different concentrations and $1 \mathrm{~mL}$ of $10 \mathrm{mM}$ TPTZ and $10 \mathrm{~mL}$ of $300 \mathrm{mM}$ acetate buffer ( $\mathrm{pH}$ 3.6) were used for a calibration curve. FRAP values were calculated and expressed as means \pm the standard deviation (SD) in millimoles of Fe (II) per gram.

\section{Conclusions}

Fourteen phenolic compounds, including two new ones- $\mathbf{1}$ and $\mathbf{2}$, were isolated from the aerial parts of M. micrantha. Their structures were identified by analysis of their spectroscopic data. Except 8 
and 9, all the other compounds were isolated from this plant species for the first time. Bioassays revealed that seven compounds demonstrated good ABTS radical cation scavenging activity more potent than L-ascorbic acid, and four compounds exhibited more potent DPPH radical scavenging activity than L-ascorbic acid. Moreover, the ferric-reducing antioxidant power (FRAP) of four compounds were comparable to or even more potent than L-ascorbic acid. This study indicates that the invasive plant M. micrantha is rich in structurally diverse phenolic compounds with functional potential beneficial for human health and is worthy of further investigation.

Supplementary Materials: The following are available online: HR-ESI-MS and NMR spectra data of compounds 1 and 2 as supporting information.

Acknowledgments: This research was supported by the National Natural Science Foundation of China (31270406, 31470422 and 31500291), the Natural Science Foundation of Guangdong Province (2014A030313742), and the Science and Technology Project of Guangdong Province (2014B020206003).

Author Contributions: L.-M. Dong and X.-C. Jia performed the isolation and structural elucidation of the chemicals and the bioassay experiments. Q.-W. Luo, Q. Zhang, B. Luo, W.-B. Liu, and X. Zhang contributed the isolation of the chemicals and the bioactive assay. Q.-L. Xu and J.-W. Tan designed and organized the study. All authors approved the final version manuscript.

Conflicts of Interest: The authors declare no conflict of interest.

\section{References}

1. Zhang, L.Y.; Ye, W.H.; Cao, H.L.; Feng, H.L. Mikania micrantha H.B.K. in China-an overview. Weed Res. 2004, 44, 42-49. [CrossRef]

2. Facey, P.C.; Pascoe, K.O.; Porter, R.B.; Jones, A.D. Investigation of plants used in Jamaican folk medicine for anti-bacterial activity. J. Pharm. Pharmacol. 1999, 51, 1455-1460. [CrossRef] [PubMed]

3. Herz, W.; Srinivasan, A.; Kalyanaraman, P.S. Mikanokryptin, a new guianolide from Mikania. Phytochemistry 1975, 14, 233-237. [CrossRef]

4. Nicollier, G.; Thompson, A.C. Essential oil and terpenoids of Mikania micrantha. Phytochemistry 1981, 20, 2587-2588. [CrossRef]

5. Boeker, R.; Jakupovic, J.; Bohlmann, F.; Schmeda-Hirschmann, G. Germacra-1,10Z,4E-dien-12,8 $\alpha$-olides from Mikania micrantha. Planta Med. 1987, 53, 105-106. [CrossRef] [PubMed]

6. Cuenca, M.D.R.; Bardon, A.; Catalan, C.A.N. Sesquiterpene lactones from Mikania micrantha. J. Nat. Prod. 1988, 51, 625-626. [CrossRef] [PubMed]

7. Huang, H.J.; Ye, W.H.; Wu, P.; Lin, L.D.; Wei, X.Y. New sesquiterpene lactones from Mikania micrantha. J. Nat. Prod. 2004, 67, 734-736. [CrossRef] [PubMed]

8. Wei, X.Y.; Huang, H.J.; Wu, P.; Cao, H.L.; Ye, W.H. Phenolic constituents from Mikania micrantha. Biochem. Syst. Ecol. 2004, 32, 1091-1096. [CrossRef]

9. But, P.P.H.; He, Z.D.; Ma, S.C.; Chan, Y.M.; Shaw, P.C.; Ye, W.C.; Jiang, R.W. Antiviral constituents against respiratory viruses from Mikania micrantha. J. Nat. Prod. 2009, 72, 925-928. [CrossRef] [PubMed]

10. Xu, Q.L.; Xie, H.H.; Xiao, H.L.; Lin, L.D.; Wei, X.Y. Two new ent-kaurene diterpene glucosides from the roots of Mikania micrantha. Phytochem. Lett. 2013, 6, 425-428. [CrossRef]

11. Xu, Q.L.; Xie, H.H.; Xiao, H.L.; Wei, X.Y. Phenolic constituents from the roots of Mikania micrantha and their allelopathic effects. J. Agric. Food Chem. 2013, 61, 7309-7314. [CrossRef] [PubMed]

12. Ríos, E.V.; León, A.; Chávez, M.I.; Torres, Y.; Ramírez-Apan, M.T.; Toscano, R.A.; Bravo-Monzón, Á.E.; Espinosa-García, F.J.; Delgado, G. Sesquiterpene lactones from Mikania micrantha and Mikania cordifolia and their cytotoxic and anti-inflammatory evaluation. Fitoterapia 2014, 94, 155-163.

13. Dong, L.M.; Jia, X.C.; Luo, Q.W.; Peng, Y.M.; Zhang, Q.; Luo, B.; Tan, J.W. Four new ent-kaurene diterpene glucosides from Mikania micrantha. Phytochem. Lett. 2017, 20, 155-159. [CrossRef]

14. Yan, J.; Bi, H.H.; Liu, Y.Z.; Zhang, M.; Zhou, Z.Y.; Tan, J.W. Phenolic compounds from Merremia umbellate subsp. orientalis and their allelopathic effects on arabidopsis seed germination. Molecules 2010, 15, 8241-8250. [PubMed]

15. Zhang, M.; Liu, W.X.; Zheng, M.F.; Xu, Q.L.; Wan, F.H.; Wang, J.; Lei, T.; Zhou, Z.Y.; Tan, J.W. Bioactive quinic acid derivatives from Ageratina adenophora. Molecules 2013, 18, 14096-14104. [CrossRef] [PubMed] 
16. Zhou, Z.Y.; Liu, W.X.; Pei, G.; Ren, H.; Wang, J.; Xu, Q.L.; Xie, H.H.; Wan, F.H.; Tan, J.W. Phenolics from Ageratina adenophora roots and their phytotoxic effects on Arabidopsis thaliana seed germination and seedling growth. J. Agric. Food Chem. 2013, 61, 11792-11799. [CrossRef] [PubMed]

17. Luo, Y.; Xu, Q.L.; Dong, L.M.; Zhou, Z.Y.; Chen, Y.C.; Zhang, W.M.; Tan, J.W. A new ursane and a new oleanane triterpene acids from the whole plant of Spermacoce latifolia. Phytochem. Lett. 2015, 11, 127-131. [CrossRef]

18. Ren, H.; Xu, Q.L.; Luo, Y.; Zhang, M.; Zhou, Z.Y.; Dong, L.M.; Tan, J.W. Two new ent-kaurane diterpenoids from Wedelia trilobata (L.) Hitchc. Phytochem. Lett. 2015, 11, 260-263. [CrossRef]

19. Ren, H.; Xu, Q.L.; Zhang, M.; Dong, L.M.; Zhang, Q.; Luo, B.; Luo, Q.W.; Tan, JW. Bioactive caffeic acid derivatives from Wedelia trilobata. Phytochem. Lett. 2017, 19, 18-22. [CrossRef]

20. Deyama, T.; Ikawa, T.; Kitagawa, S. The constituents of Eucommia ulmoides Oliv. V. isolation of dihydroxydehydrodiconiferyl alcohol isomers and phenolic compounds. Chem. Pharm. Bull. 1987, 35, 1785-1789. [CrossRef]

21. Du, Q.Z.; Jerz, G.; Shen, L.Q.; Xiu, L.; Winterhalter, P. Isolation and structure determination of a lignan from the bark of Salix alba. Nat. Prod. Res. 2007, 21, 451-454. [CrossRef] [PubMed]

22. Wang, L.; Li, F.; Yang, C.Y.; Khan, A.A.; Liu, X.; Wang, M.K. Neolignans, lignans and glycoside from the fruits of Melia toosendan. Fitoterapia 2014, 99, 92-98. [CrossRef] [PubMed]

23. Nakanishi, T.; Iida, N.; Inatomi, Y.; Murata, H.; Inada, A.; Murata, J.; Lang, F.A.; Linuma, M.; Tanaka, T. Neolignan and flavonoid glycosides in Juniperus communis var. Depressa. Phytochemistry 2004, 65, $207-213$. [CrossRef] [PubMed]

24. Shen, Y.C.; Hsieh, P.W.; Kuo, Y.H. Neolignan glucosides from Jasminum urophyllum. Phytochemistry 1998, 48, 719-723. [CrossRef]

25. Ishikawa, T.; Fujimatu, E.; Kitajima, J. Water-soluble constituents of anise: New glucosides of anethole glycol and its related compounds. Chem. Pharm. Bull. 2002, 50, 1460-1466. [CrossRef] [PubMed]

26. Lin, S.; Wang, S.J.; Liu, M.T.; Gan, M.; Li, S.; Yang, Y.; Wang, Y.; He, W.; Shi, J. Glycosides from the stem bark of Fraxinus sieboldiana. J. Nat. Prod. 2007, 70, 817-823. [CrossRef] [PubMed]

27. Gan, M.L.; Zhang, Y.L.; Lin, S.; Liu, M.T.; Song, W.X.; Zi, J.C.; Yang, Y.C.; Fan, X.N.; Shi, J.G.; Hu, J.F.; et al. Glycosides from the root of Iodes cirrhosa. J. Nat. Prod. 2008, 71, 647-654. [CrossRef] [PubMed]

28. D'Abrosca, B.; DellaGreca, M.; Fiorentino, A.; Monaco, P.; Previtera, L.; Simonet, A.M.; Zarrelli, A. Potential allelochemicals from Sambucus nigra. Phytochemistry 2001, 58, 1073-1081. [CrossRef]

29. Miyase, T.; Kuroyanagi, M.; Noro, T.; Ueno, A.; Fukushima, S. Studies on sesquiterpenes from Macroclinidium trilobum Makino. II. Chem. Pharm. Bull. 1985, 33, 4445-4450. [CrossRef]

30. Jutiviboonsuk, A.; Zhang, H.; Tan, G.T.; Cuiying, M.; Hung, N.V.; Cuong, N.M.; Bunyapraphatsara, N.; Soejarto, D.D.; Fong, H.H.S. Bioactive constituents from roots of Bursera tonkinensis. Phytochemistry 2005, 66, 2745-2751. [CrossRef] [PubMed]

31. Matsushita, H.; Miyase, T.; Ueno, A. Lignan and terpene glycosides from Epzmedium sagittatum. Phytochemistry 1991, 30, 2025-2027. [CrossRef]

32. Zdero, C.; Bohlmann, F.; Niemeyer, H.M. Sesquiterpene lactones from Perityle emoryi. Phytochemistry 1990, 29, 891-894. [CrossRef]

33. Song, C.Z.; Wang, Y.H.; Hua, Y.; Yan, H.; Wu, Z.K.; Du, Z.Z. Chemical constituents of Clematis montana. Chin. J. Nat. Med. 2008, 6, 116-119.

34. Wang, Z.J.; Zhao, Y.Y.; Wang, B.; Min, A.T.; Chen, Y.Y. Depsides from Prunella vulgaris. Chin. Chem. Lett. 2000, 11, 997-1000.

35. Baderschneider, B.; Winterhalter, P. Isolation and characterization of novel benzoates, cinnamates, flavonoids, and lignans from riesling wine and screening for antioxidant activity. J. Agric. Food Chem. 2001, 49, $2788-2798$. [CrossRef] [PubMed]

36. Xin, X.L.; Aisa, H.A.; Wang, H.Q. Flavonoids and phenolic compounds from seeds of the Chinese plant Nigella glandulifera. Chem. Nat. Comp. 2008, 44, 368-369. [CrossRef]

37. Erenler, R.; Sen, O.; Aksit, H.; Demirtas, I.; Yaglioglu, A.S.; Elmastas, M.; Telci, İ. Isolation and identification of chemical constituents from Origanum majorana and investigation of antiproliferative and antioxidant activities. J. Sci. Food Agric. 2016, 96, 822-836. [CrossRef] [PubMed]

38. Willcox, J.K.; Ash, S.L.; Catignani, G.L. Antioxidants and prevention of chronic disease Crit. Rev. Food Sci. Nutr. 2004, 44, 275-295. [CrossRef] [PubMed] 
39. Rai, S.; Wahile, A.; Mukherjee, K.; Saha, B.P.; Mukherjee, P.K. Antioxidant activity of Nelumbo nucifera (sacred lotus) seeds. J. Ethnopharmacol. 2006, 104, 322-327. [CrossRef] [PubMed]

40. Ma, Q.; Xie, H.H.; Li, S.; Zhang, R.F.; Zhang, M.W.; Wei, X.Y. Flavonoids from the pericarps of Litchi chinensis. J. Agric. Food Chem. 2014, 62, 1073-1078. [CrossRef] [PubMed]

Sample Availability: Not available.

(C) 2017 by the authors. Licensee MDPI, Basel, Switzerland. This article is an open access article distributed under the terms and conditions of the Creative Commons Attribution (CC BY) license (http://creativecommons.org/licenses/by/4.0/). 